\title{
High-energy events in the Frasnian-Famennian boundary interval of the Płucki section in the Holy Cross Mountains, Poland
}

\author{
Piotr Szrek ${ }^{1,2}$ (D) Sylwester Salwa ${ }^{3}$
}

Received: 19 June 2019 / Accepted: 8 January 2020 / Published online: 25 January 2020

(c) The Author(s) 2020

\begin{abstract}
Of all the Devonian stratigraphic boundaries, the Frasnian-Famennian transition (372.2 $\pm 1.6 \mathrm{Ma})$ preserves the record of one of the most significant crises in the history of life, the final stages of which lie buried in the distinctive Kellwasser limestone. The Kellwasser facies occur in Western and Central Europe and the commonly cited Płucki area of Poland's geologically rich Holy Cross Mountains is the only site in that region where the Frasnian-Famennian boundary is considered to occur within Kellwasser facies. At this locality, the limestone contains slump structures, comprising contorted beds and folds. Actually the Kellwasser-like limestone from Płucki is composed of a mixture of three distinct types of sediment, occurring as clasts, commonly deformed and sheared, and matrix, rather than being one homogenous bed, as previously considered. Thus, earlier studies and interpretations of this limestone may need revising. This paper documents the evidence for sediment erosion and reworking, debris flows, sliding and soft-sediment deformation on a submarine slope, and suggests that seismic events were the likely triggering mechanism for slumping and resedimentation.
\end{abstract}

Keywords Kellwasser limestone $\cdot$ Slumps $\cdot$ Frasnian-Famennian boundary $\cdot$ Holy Cross Mountains $\cdot$ Tectonic activity

\section{Introduction}

The Devonian stratigraphic interval close to the Frasnian-Famennian boundary preserves the effects of one of the largest mass extinction events in the history of life: namely, the collapse of the stromatoporoid-coral reef biota, an overall breakdown of carbonate production as well as the disappearance of many nektonic species (e.g., House 2002; Bond et al. 2004; Racki 2005; McGhee 2013). It is also widely accepted that the causes of this mass extinction were Earth-related rather than a global cosmic catastrophe (Racki 1998, 2005; Ma et al. 2016; Racki et al. 2018).

In most stratigraphic sections, the Frasnian/Famennian boundary is characterized by the presence of Upper

Piotr Szrek

piotr.szrek@pgi.gov.pl

1 Piotr Szrek, Polish Geological Institute-National Research Institute, 4 Rakowiecka Street, 00-975 Warsaw, Poland

2 Faculty of Geology, University of Warsaw, 93 Żwirki and Wigury Street, 02-089 Warsaw, Poland

3 Sylwester Salwa, Holy Cross Mountains Branch of the Polish Geological Institute-National Research Institute, 21 Zgoda Street, 25-953 Kielce, Poland
Kellwasser facies (Bratton et al. 1999; Gereke and Schindler 2012; Rakociński et al. 2016), which have become the focus of attention. The bituminous limestone and black shale units of the Kellwasser facies are characterized by the occurrence of pelagic fossils. One of the best-known sections with a Kellwasser horizon occurs at Płucki in the Holy Cross Mountains, Poland, where many detailed analyses have been undertaken (Racki et al. 2002; Bond et al. 2004; Woroncowa-Marcinowska 2006).

The first account of the disturbed nature of the Upper Devonian deposits from the Płucki area was presented by Radwański and Roniewicz (1962), who described submarine slumps in the lower Famennian at Łagów (1 km from Płucki) and subsequently reported similar features from other locations in the Holy Cross Mountains (e.g., Szulczewski 1968, 1971, 1989; Kaźmierczak and Goldring 1978; Vierek 2007, 2013). These authors interpreted the mechanism for the initiation of slumps as a result of either tectonic activity or to the effect of storms.

Descriptions of the site in Płucki were provided by Sobolev (1912) and Czarnocki in the 1920s (general geology field notes, unpublished until 1989), and then by Makowski (1963, 1971). Dzik (1985) is credited with describing the 
rich fauna of goniatites that occur within the black bituminous limestone.

Details of the section exposed in Płucki were published by Szulczewski (1989), who was the first to employ the term "Upper Kellwasser Limestone" in reference to the black bituminous limestone which is found there. In the past 20 years, a number of different papers on the stratigraphy, geochemistry and paleontology of the site have been published (e.g., Ginter 1995, 2002; Ivanov and Ginter 1997; Dzik 2002, 2007; Filipiak 2002; Racki et al. 2002; Bond et al. 2004; Woroncowa-Marcinowska 2006; Janiszewska et al. 2007; Szrek 2007a, 2008; Dworczak and Szrek 2016). In particular, the Płucki locality is one of the richest for placoderm remains with about 500 specimens collected. This locality has also been the source of material for several scientific projects and MSc and PhD theses (e.g., K. Janiszewska unpub. M.Sc. thesis, Univ. of Warsaw, 2008; P. Szrek unpub. Ph.D. thesis, Univ. of Warsaw, 2009; P. Dworczak unpub. M.Sc. thesis, Adam Mickiewicz Univ., Poznan, 2016). All of the authors mentioned above have published numerous generalized and specific interpretations of this particular section but there are differences in their descriptions of the composition of the various lithological units (Fig. 1). In 2015, our field work revealed that the succession at Płucki is much more complicated than previously described, mainly because of the large lateral variability in the section as reflected by varying thicknesses of certain layers over distances of several meters (Figs. 3, 10). The aim of this article is to report new insights of the strata exposed.

\section{Geological setting}

The outcrop in Płucki near Łagów is located in the central part of the Holy Cross Mountains, about $36 \mathrm{~km}$ E of Kielce and $190 \mathrm{~km} \mathrm{~S}$ of Warsaw, (Fig. 2a) at GPS coordinates: $50^{\circ} 47^{\prime} 11.2^{\prime \prime} \mathrm{N}, 21^{\circ} 04^{\prime} 39.1^{\prime \prime} \mathrm{E}$. The dip of the strata is about $32-36^{\circ}$ toward the SSE.

The Plucki section is one of the key places to study the Upper Devonian of the Holy Cross Mountains. There are two outcrops located to the northeast of Łagów town on the southern slope of the Łagowica River Valley, which is geologically situated in the eastern part of the Kielce-Łagów Synclinorium. The Upper Devonian sequence, the so-called Łagów Beds (Sobolev 1912; Czarnocki 1950, 1989; Wolska 1967; Dzik 1985, 2006) in the Łagowica Valley, consists of a deep-water succession of more than $150 \mathrm{~m}$ of rhythmically bedded marly limestone and shale, deposited in the Łysogóry Basin (Racki 1993a, b; Fig. 2b). The Łagów Beds range stratigraphically from the Frasnian late rhenana Zone to the Famennian triangularis Zone (Racki et al. 2002).

The Lower and Upper Kellwasser horizons are both characterized by the occurrence of black bituminous

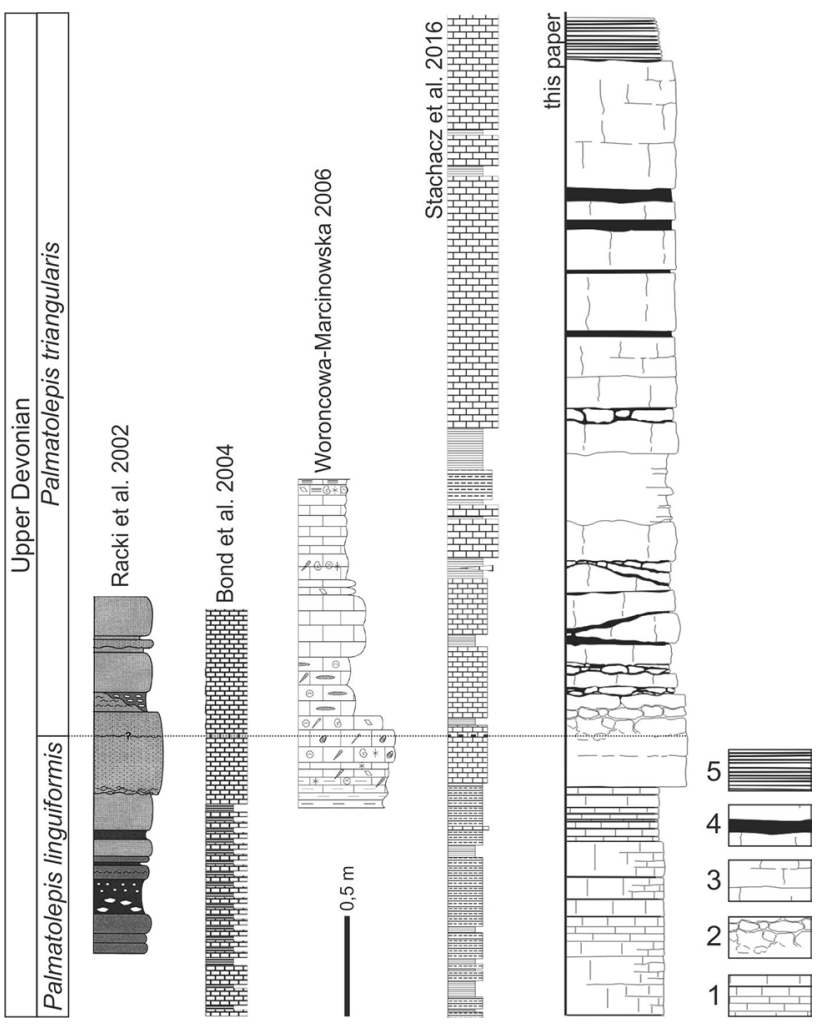

Fig. 1 Comparison of stratigraphic settings of the $\mathrm{F} / \mathrm{F}$ transition in the Płucki locality (Holy Cross Mountains, Poland) performed (in order from the left to the right) by Racki et al. (2002, Fig. 6), Bond et al. (2004, Fig. 8), Woroncowa-Marcinowska (2006, Fig. 2) and Stachacz et al. (2016, Fig. 3). 1-marlstone interbedded with silty shale; 2-dolomitic limestone; 3-micritic limestone; 4-mudstone; 5-shale. Dotted line points to the most probable position of the Frasnian-Famennian boundary

limestones, which have been well dated based on conodonts. The origin of these two horizons is connected to anoxic episodes in the Late Devonian (Racki et al. 2002; Bond et al. 2004; Janiszewska et al. 2007; Szrek 2007a; Rakociński et al. 2016; Stachacz 2016).

The Upper Kellwasser horizon (Fig. 2c) is about $0.5-\mathrm{m}$ thick and records several events that document a hiatus in the geological record (Janiszewska et al. 2007; Szrek 2007a; Szrek and Ginter 2008). The entire horizon is heterogeneous, with the Frasnian-Famennian boundary situated within the middle part, according to the precise analysis presented by Racki et al. (2002) and Janiszewska et al. (2007). Płucki was once referred to as a Lagerstätte (Szrek 2011), in view of the large number of well-preserved fossils found in this section, but the use of this term is widely considered to be a misinterpretation considering the fragmentary state of preservation (particularly the fish) and the lack of mineralized soft tissues. However, this horizon may still be called at least a Konzentrat-Lagerstätte. 

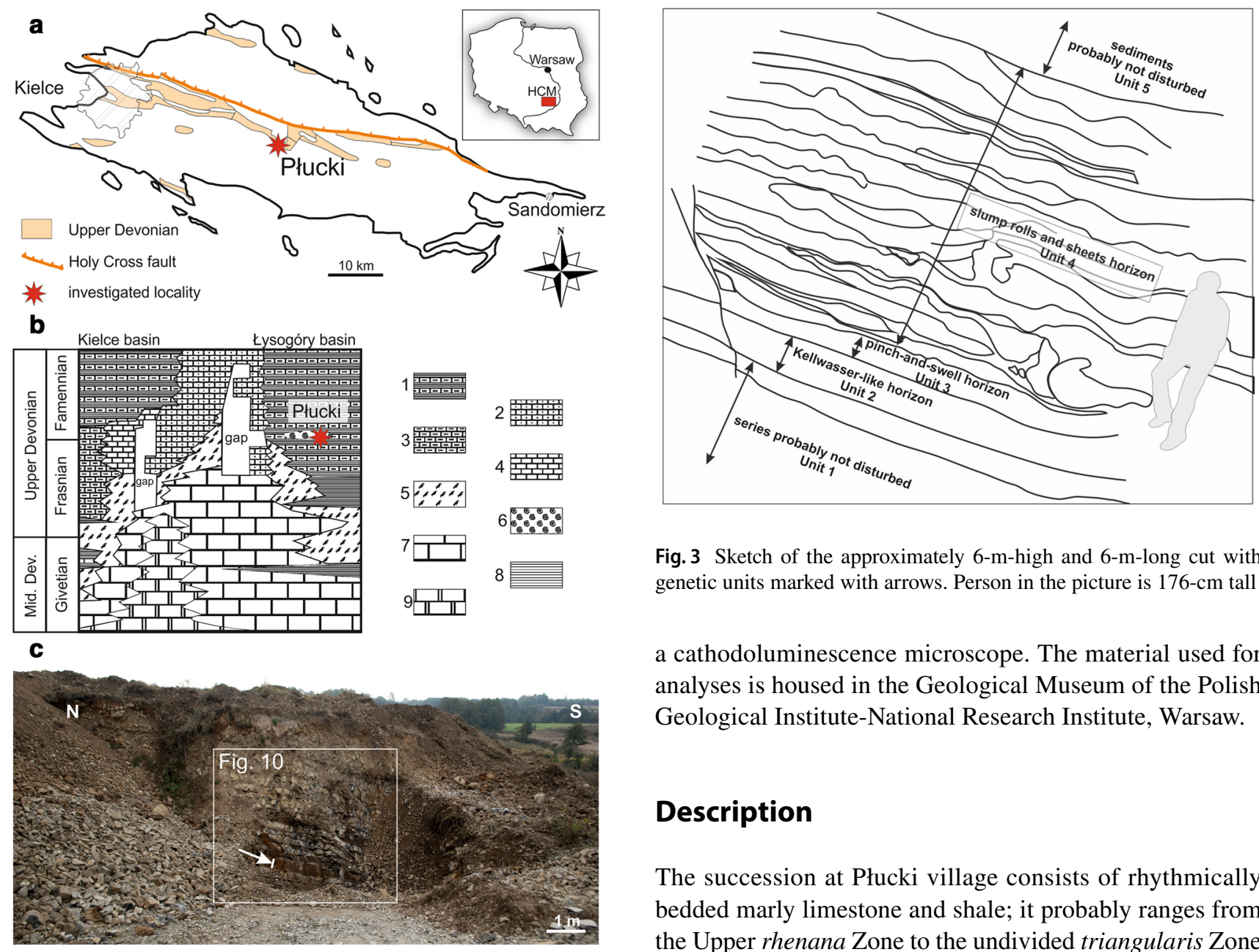

Fig. 3 Sketch of the approximately 6-m-high and 6-m-long cut with genetic units marked with arrows. Person in the picture is $176-\mathrm{cm}$ tall

a cathodoluminescence microscope. The material used for analyses is housed in the Geological Museum of the Polish Geological Institute-National Research Institute, Warsaw.

\section{Description}

The succession at Płucki village consists of rhythmically bedded marly limestone and shale; it probably ranges from the Upper rhenana Zone to the undivided triangularis Zone (Racki et al. 2002). Five units have been distinguished in

Fig. 2 Location of the investigated outcrop in the Holy Cross Mountains. a Location map of the Holy Cross Mountains (HCM), central Poland (modified from Kowalczewski 1971). b Diagrammatic cross section through the Holy Cross Mountains from the Givetian to the top of the Upper Devonian (after Szulczewski 1995, modified) with the probable position of the localities investigated (1-marly limestone and shale; 2 -condensed cephalopod and crinoidal limestone; 3-marly limestone; 4-bedded limestone; 5-calcirudite; 6-cephalopod limestone; 7-massive and bedded limestone; 8-clayey and marly shale; 9-dolomite). c General view of the outcrop; picture taken from the WNW. Arrow points to the Kellwasser-like horizon

\section{Material and methods}

With the aid of a heavy excavator, a new section was uncovered to a depth of $6 \mathrm{~m}$ and a width of more than $6 \mathrm{~m}$ (Fig. 2c). The section was washed with water and brushed thoroughly to reveal a particularly interesting surface, which has been further analyzed starting from the bottom of the marl that lies beneath the Upper Kellwasser horizon which was the deepest level in the outcrop due to the technical limitations of the excavator. For sedimentological analysis, 15 thin sections and 46 polished hand samples were prepared and studied under a transmitted-light microscope and the section studied: (1) an undisturbed unit of marlstone interbedded with silty shale, (2) the Upper Kellwasser-like horizon, (3) a pinch-and-swell horizon, (4) a slump roll and sheet unit, and (5) an upper undisturbed unit of marlstone interbedded with silty shale (Fig. 3).

\section{Unit 1: Marlstone interbedded with silty shale}

The lowest unit exposed consists of marlstone, beds around $10-\mathrm{cm}$ thick, interbedded with silty shale, up to $5-\mathrm{cm}$ thick. Horizontal lamination occurs in both lithological types; however, some marlstone is slightly bioturbated (Stachacz et al. 2016). The thickness of this unit visible in the outcrop is about $1 \mathrm{~m}$ but exposures nearby suggest a total thickness of about $20 \mathrm{~m}$ (Racki et al. 2002).

\section{Unit 2: Upper Kellwasser-like horizon}

The Kellwasser-like horizon is in total about 0.5-m thick (Fig. 4) and is characterized by the occurrence of erosional surfaces, current-oriented and fragmented nautiloids (Szrek and Ginter 2007, Figs. 4b, 8) and goniatite shells 

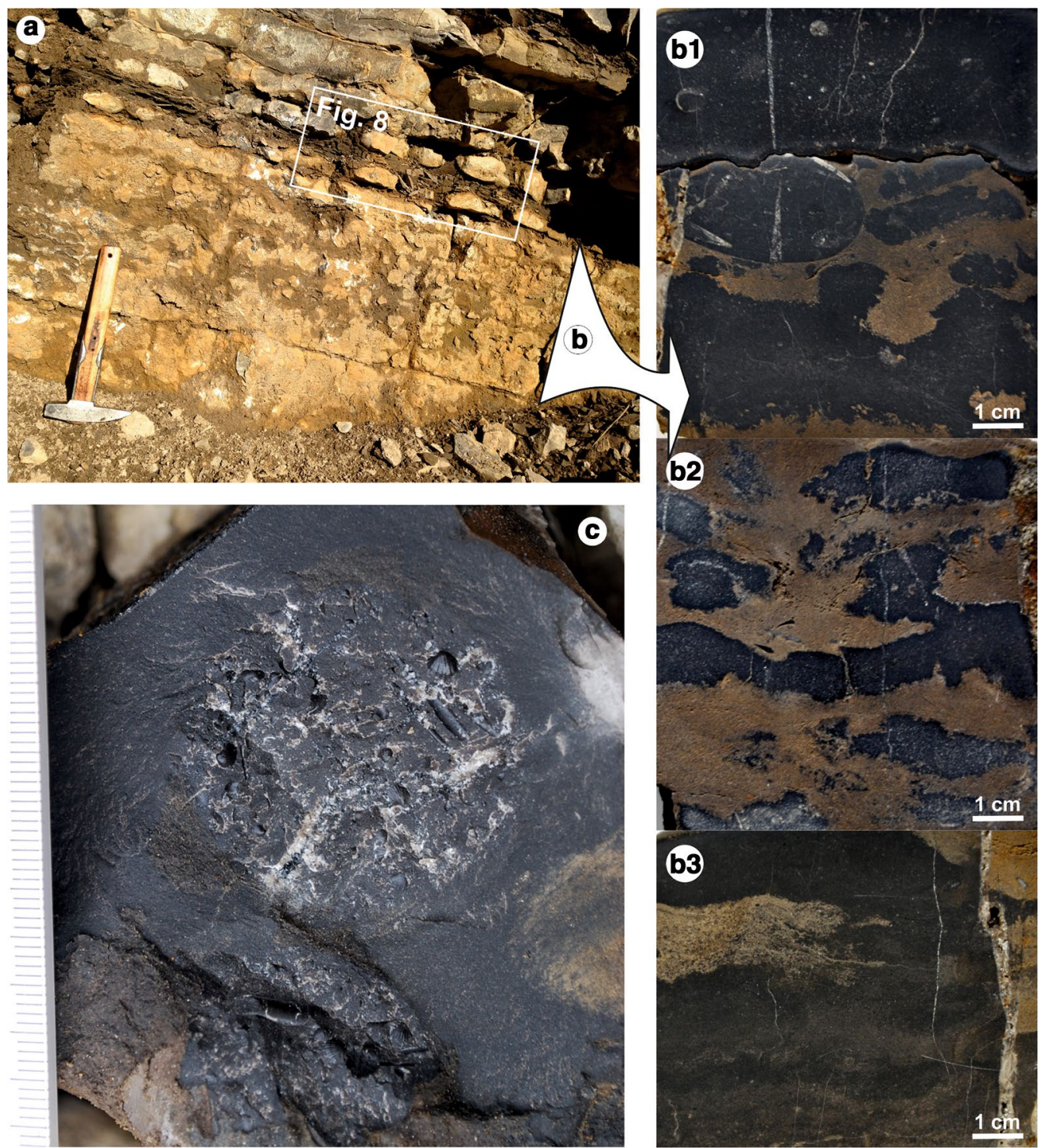

Fig. 4 Details of Unit 2, the Upper Kellwasser-like part of the section. a Kellwasser-like horizon (the hammer lying on the floor of the Kellwasser package). b1-3 Cross section through the Kellwasser-like limestone showing its internal structure (all three pictures show true

(Janiszewska et al. 2007). The oriented nautiloids demonstrate a NEE direction of palaeocurrents. The lower, entirely Frasnian part (up to $30 \mathrm{~cm}$ ) is characterized from bottom to top by a marl which rapidly and abruptly changes upwards into micritic limestone (Fig. 1). The middle segment of almost $10-\mathrm{cm}$ thickness shows the highest concentration of fossils, particularly of cephalopods and minute arthrodire placoderms. According to the precise analysis of Janiszewska et al. (2007), the Frasnian-Famennian boundary is situated within this part of the horizon (Fig. 1). The uppermost $10 \mathrm{~cm}$ belong entirely to the basal Famennian and is characterized by numerous invertebrate and fish fossils. Locally, the upper part of the Kellwasser-like horizon is subdivided thickness of the horizon but have been taken in different places within it). c Specimen showing a clast of the black fossiliferous limestone in a dolomitic non-fossiliferous limestone

by thin, irregular ferrous crusts. The internal structure of the Kellwasser-like horizon is characterized by the occurrence of a breccia-like structure (Fig. 4b1-3, c), composed of three lithological varieties (Figs. 5a-c, 6a, b): (1) compact black, fossiliferous limestone, (2) black limestone with few or no fossils, both occurring as clasts, and (3) weakly cemented, dark-brown dolomitic limestone. These microfacies types occur in varying proportions depending on their positions within the unit. Sizes of clasts vary from a few $\mathrm{mm}$ to several $\mathrm{cm}$. Their shredded-sheared character is well recognizable and occurs exclusively within the upper part of the Unit 2. Compact black, fossiliferous limestone usually occurs in a form of pebbles. Within these, most of the small fossils 

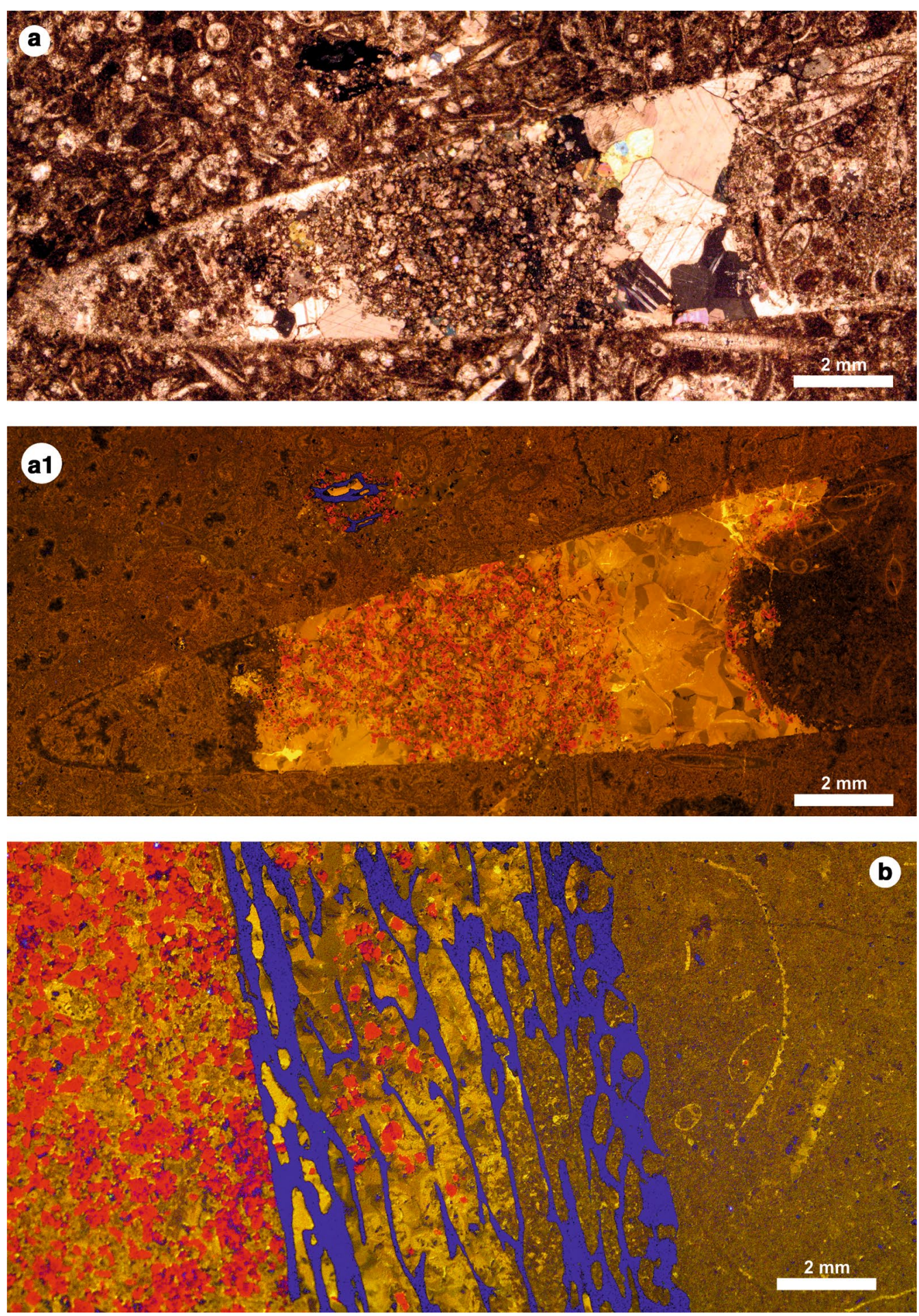

Fig. 5 Selected thin sections of Unit 2, the Upper Kellwasser-like horizon. A (transmitted light), A1 (cathodoluminescence)—nautiloid shell fill with dolomitic limestone (1) and black, fossiliferous lime-

have been found, unlike the weakly cemented, dark-brown dolomitic limestone, where large bones (up to $30 \mathrm{~cm}$ long) and cephalopod fragments are very common. Apart from fossils within the weakly cemented, dark-brown dolomitic stone (2) in fossiliferous limestone (3); b-placoderm bone fragment (1) filled partially with dolomitic limestone (2) and fossiliferous limestone (3)

limestone, nodules composed of compact black, fossiliferous limestone are present and they are usually cracked.

The fossils found in the Upper Kellwasser-like horizon are generally well preserved, especially the small 

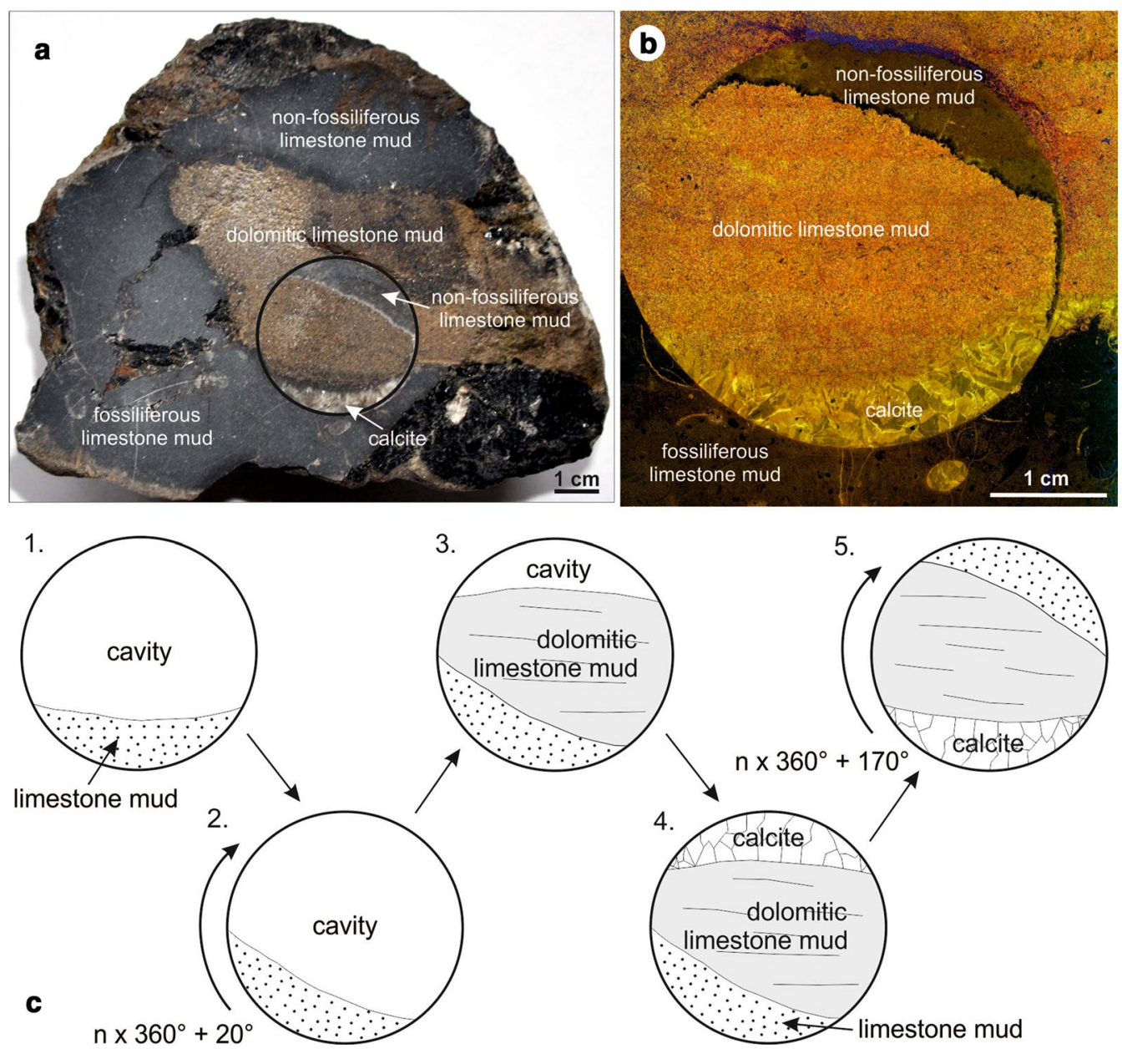

Fig. 6 Geopetal structure within the cross section of a nautiloid shell. a General picture of the specimen. b Thin section of the part with nautiloid shell, rotated and filled with sediment at different stages (1-5)

invertebrates. The horizon contains, apart from the described pelagic cephalopods (Makowski 1971; Dzik 1985; Woroncowa-Marcinowska 2006), many benthic elements such as bivalves and brachiopods (Szrek and Ginter 2007) and likewise several bottom-dwelling fish (Dworczak and Szrek 2016). Within the brachiopods and nautiloids, geopetal structures in rotated positions have been frequently observed (Fig. 6).

Numerous vertebrate remains are represented mainly by arthrodire placoderms and show various states of preservation, reflecting their history before subsequent burial (Szrek and Wilk 2018). Most of the fragments are disarticulated and show marks of abrasion (Fig. 7a). The only articulated specimens are represented by skull-roofs and belong to small individuals (comp. Ivanov and Ginter 1997, Fig. 4a). Several samples contain rare disarticulated elements. The remains of large placoderms, whose heads reached more than $0.5 \mathrm{~m}$ in length, are always disarticulated and show signs of mechanical damage prior to fossilization (Szrek and Wilk 2018, Figs. 1, 2, 3, 4 and 5), manifested by the occurrence of numerous fractured and broken bones surrounded by sediment (Fig. 7a).

Within the assembled vertebrate remains, there are two distinct types of preservation (Szrek in press). The first is characterized by a relatively good state of almost fully articulated skeletons (Ivanov and Ginter 1997, Fig. 4a) and/ or associations of disarticulated remains of smaller placoderms. The second type of preservation consists of fragments of larger disarticulated placoderms, characterized by broken and abraded plates (Fig. 7a; Szrek and Wilk 2018, Figs. 1, 2, 3, 4, 5). Notably, almost all of these armored nektonic fish remains are found in the dark-brown limestone rather than in the black limestone, which in contrast contains diverse invertebrates. Another common bioclast within the brown limestone of the Upper Kellwasser-like horizon is represented by styliolinids and tentaculites within the brown limestone (Fig. 7c).

Above the Upper Kellwasser-like horizon (units 3-5), fossils are much less numerous or are totally absent, and comprise only pelagic invertebrates. 
a

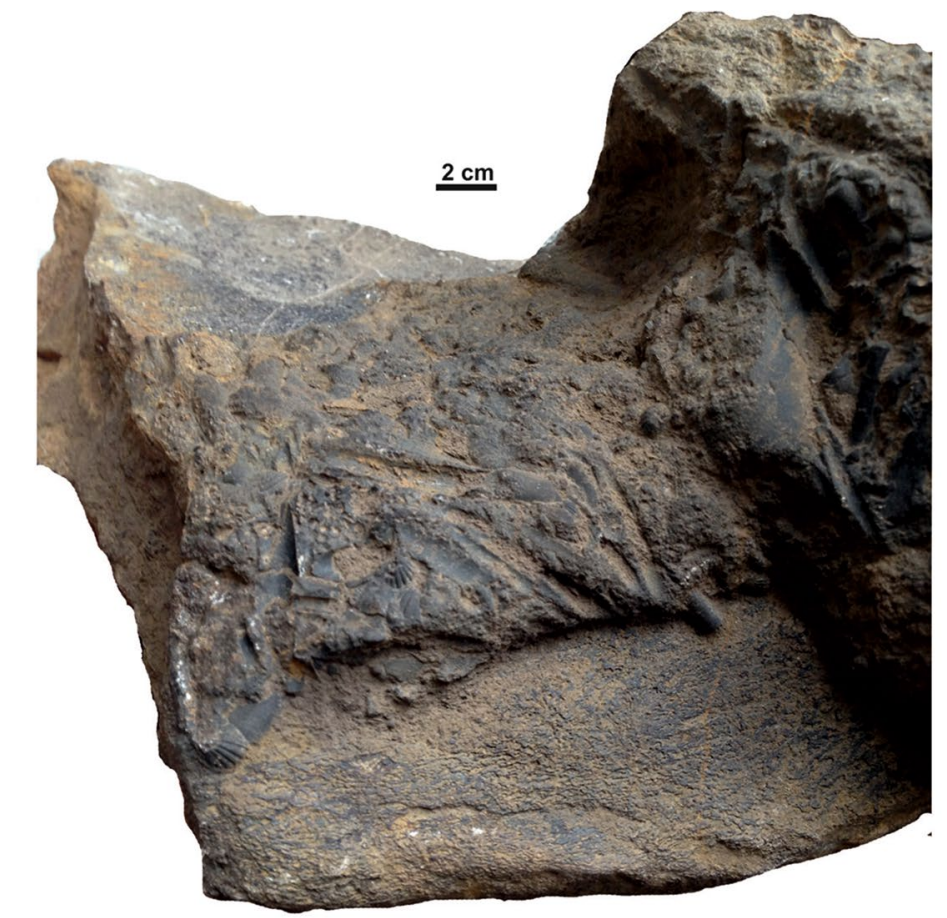

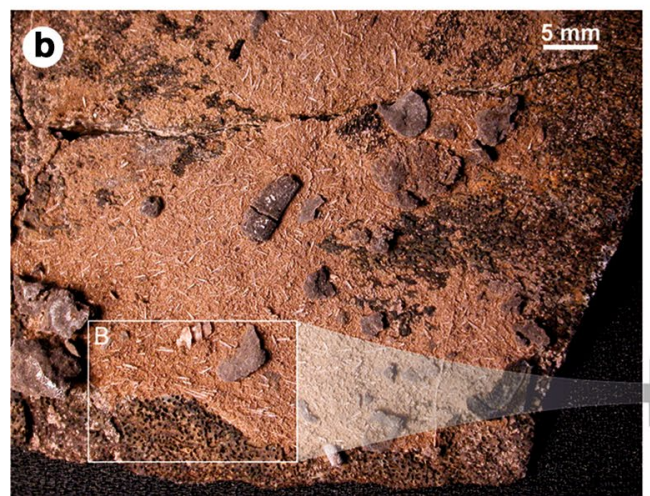

Fig. 7 Placoderm remains fragmented during slumping and/or reworking. a A part of a median dorsal plate of a large representative of the placoderm Dunkleosteus, with the side covered with abraded fossiliferous dolomitic limestone full of orthocone nautiloids; the

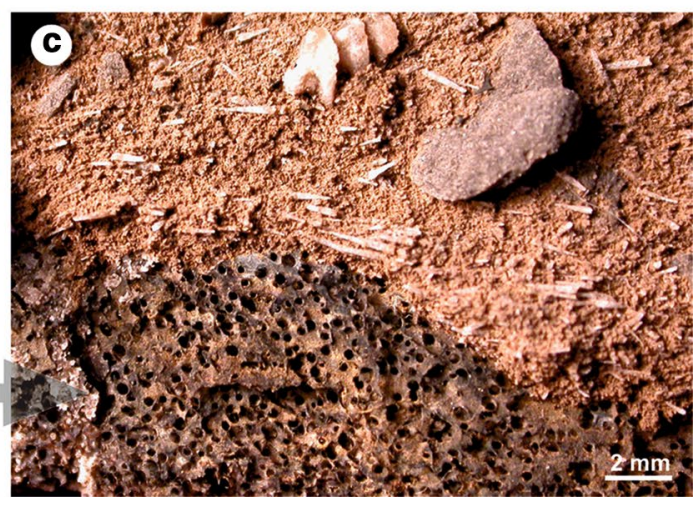

clast is prepared from the dark-brown sediment from the Upper Kellwasser-like horizon. b Surface of placoderm plate corroded and covered with sediment; c Magnified area marked on A with numerous, oriented tentaculitids

\section{Unit 3: pinch-and-swell-like structures}

The beds directly above contrast sharply with the Kellwasser-like horizon since they are composed mostly of micritic limestone, marly limestone and silty shale (see also Woroncowa-Marcinowska 2006). Unit 3 is about 30-cm thick (4A) and consists of three beds of micritic limestone nodules with surrounding silty shale (Figs. 4a, 8). The lower and middle layers of the unit consist of thin (less than $10 \mathrm{~cm}$ ) horizons composed of nodules embedded in dark shale. The nodules are arranged horizontally at a distance of about $5 \mathrm{~cm}$ from each other (Fig. 8). Nodules are asymmetric, with dimensions varying from 5 to $20 \mathrm{~cm}$ in length and $4-12 \mathrm{~cm}$ in thickness. In cross section, they usually have a pillow-like

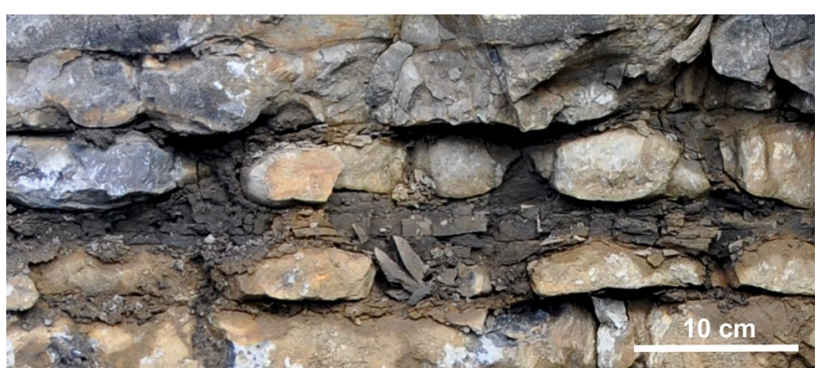

Fig. 8 Pinch-and-swell structures within shale and limestone above the Upper Kellwasser-like horizon 
oval shape, which is locally deformed into a more irregular shape. The nodules have sharp boundaries with the surrounding dark shale. Traced laterally over half a meter, the nodules are disconnected with a few $\mathrm{cm}$ between each. The internal structure of the nodules is characterized by a homogenous lower part with a lamination that is folded laterally upwards. In a few samples, the nodules contain no lamination but are fractured with dark shale in the cracks.

The upper part of unit 3 is less than $10-\mathrm{cm}$ thick and is characterized by the presence of reworked pebbles of fossiliferous black limestone in a dark-gray limestone.

\section{Unit 4: slump rolls and sheets}

Unit 3 with the limestone nodules is followed by Unit 4 consisting of highly disturbed beds of about $4 \mathrm{~m}$ in thickness of micritic limestone alternating with shale $10-20-\mathrm{cm}$ thick (Figs. 3, 9). The disturbances include folds, as well as dismembered layers and nodules with geopetal structures in various positions preserved within brachiopod and nautiloid shells (Figs. 6, 9a). The folds incorporate individual limestone beds which thicken in the region of the overfolds (Fig. 9a) which usually end the bed's continuity (Fig. 10a, b). Where beds are disrupted, the original horizontal lamination disappears and internal laminae become disordered (Fig. 9c). Fold axes are commonly oriented at about $26^{\circ}$ to NNE and suggest a southeasterly movement. Thickness variability is apparent in this part of the section and in some places, the beds decrease in thickness from 70 to $0 \mathrm{~cm}$ over a distance of $2 \mathrm{~m}$ (Fig. 10). Some features (e.g., fold-axis orientation, southern convergence of their axial surfaces and slices and, additionally directions based on nautiloid shells) have a SSE orientation which fits the reconstructed current direction based on the study of adjacent nautiloid shells (Szrek and Ginter 2007, Fig. 8) which is longitudinal to down-slope. The shale intercalated within the limestone beds has also been strongly folded, with the continuity of the limestone beds not interrupted or broken. The thickness of shale varies from several tens of $\mathrm{cm}$ to zero. The original lamination in the shale is poorly visible or absent. In places where shale reaches more than $10 \mathrm{~cm}$ in thickness, rounded and structureless clasts of limestone as large as $10 \mathrm{~cm}$ are present.
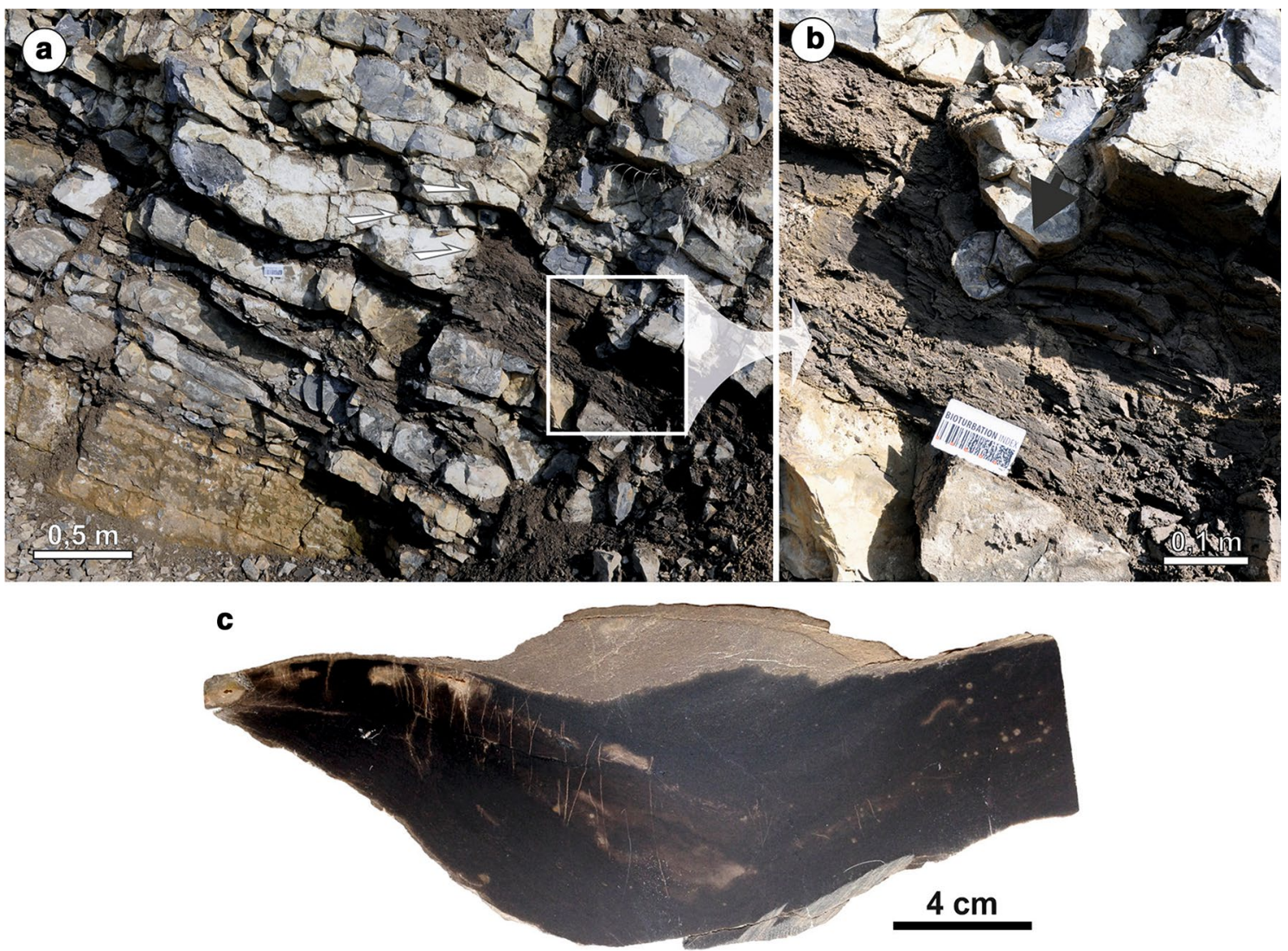

Fig. 9 a Details of the slump deformations in the section. a Slump-folded part of a limestone bed with a thinner flank towards the WNW (left) and a thicker limb towards the ESE (right); the original horizontal lamination has disappeared 


\section{Unit 5: undisturbed marly limestone beds and shale}

Up to $1-\mathrm{m}$ thickness, Unit 5 is observed at the top of the excavation. In this part of the section, there are no folds or disturbances, apart from subtle variations in bed thickness from tectonic shearing.

\section{Discussion}

The Frasnian-Famennian biodiversity crisis is especially well recorded in reef development and its eventual collapse. Before the crisis, reefs (in general terms) covered $5000,000 \mathrm{~km}^{2}$ globally (McGhee 2013); whereas after, reefs survived to cover only around $5000 \mathrm{~km}^{2}$ (Copper 1994; McGhee 2013). This reduction is also visible in the fossil record of the Holy Cross Mountains, where all bioherms disappeared by the end of the Frasnian and tectonic activity caused unconformities, stratigraphic gaps and synsedimentary block-faulting in the Famennian deposits (e.g., Szulczewski 1971; Racki 1993a, 1998; Racki and Baliński 1998; Skompski and Szulczewski 2000; Racki et al. 2002; Fig. 2b). Thus, the final disappearance of reef organisms in the Holy Cross Mountains most probably resulted from depth changes caused by tectonic movements, along with anoxia in restricted basins.

The recent excavations of the Płucki section have allowed the further study of the site's lateral variability of lithology, which has been given little attention in the past. Now, the Upper Kellwasser-like horizon can be more thoroughly analyzed in several cross sections at 6-7-m distance. The deformations described above resulted from synsedimentary submarine movements and are manifested by the disintegration and redeposition of sediments and plastic deformation (Figs. 3, 4b, c, 6, 10, 11), as discussed below.

The succession at Plucki is interpreted to be the result of three major synsedimentary resedimentation events (see Figs. 3, 10, 11), affecting the Upper Kellwasser-like horizon (Unit 2), the pinch-and-swell horizon (Unit 3), and the limestone with slump rolls and sheets (Unit 4).

The Upper Kellwasser-like horizon occurs within the slope of the deep-shelf part of the Łysogory Basin of the Holy Cross Mountains and is regarded as a shallower sedimentary environment than the rest of the profile which is represented by deep-shelf Łagów Beds (Rakociński et al. 2016). Redeposition of the material may be a reason for the occurrence of shallow-water sediments. This is supported by conodont biofacies which change from a deeper-water environment in the linguiformis Zone to a shallower one in the Early triangularis Zone (Matyja and Narkiewicz 1992, 1995). At Plucki this change was noted by previous authors (e.g., Racki et al. 2002; Janiszewska et al. 2007). For the equivalent-age Janczyce I section (about $20 \mathrm{~km}$ from Płucki),
Matyja and Narkiewicz (1992) postulated that shallow-water faunal elements represented autochthonous constituents during eustatic shallowing. For the Płucki section, the shallowing resulted in in situ reworking of the sediments and the origin of the internal structure of the Kellwasser-like horizon. Such a scenario is plausible for homogenous sediment without any trace of redeposition. Such conditions are not observed for the discussed horizon in Plucki. In our opinion, instead of sea-level change (not excluded totally), more influential is redeposition of shallower-water sediment to the deeper part of the basin on the slope. The composition and internal structure of this horizon suggest that the dark-brown limestone as well as the black fossiliferous and non-fossiliferous dolomitic limestone were transported en masse from the shallower part of the basin, because they usually contain abraded clasts in a form of conglomerate (Figs. 4b, c, 6). The already identified source area for redeposited deposits was located in the western part of the region (around Kielce city; $36 \mathrm{~km}$ from Płucki), where shallow-water fossiliferous facies (including subaerial exposure features) have been documented (e.g., Szulczewski 1971; Skompski and Szulczewski 2000). However, it has not been fully resolved that this area was the source for the Płucki area. Within the debris flows, dolomitic limestone fragments were combined as they traveled with dark-brown partially lithified limestone and were finally deposited as a sheet of black sediment with clasts of black dolomitic limestone embedded in dark-brown limestone. Black dolomitic limestone must have been partially lithified when the slump process was triggered; whereas, the brown limestone still exhibited its loose nature, confirmed by the numerous broken margins and jagged shapes of clasts (Fig. 4b, c). Geopetal structures also point to transport with shells of brachiopods or nautiloids being filled with dolomitic sediment (Figs. 5, 6). This suggests that such shells must have been lying buried below the seafloor for some time, while calcite was precipitated in cavities inside the shell. Afterwards, they were transported (possibly within the slump) and rotated to different orientations (Fig. 6). The presence of dolomitic limestone pebbles and clasts in the Kellwasser-like horizon suggests erosion and reworking in the source area. The Kellwasser-like horizon (Unit 2), the pinch-and-swell horizon (Unit 3) and the slumped Unit 4 above, could have been formed during separate seismic events. Thus, the slump character of the most of the sections studied (Racki et al. 2002, Fig. 9; Bond et al. 2004, Fig. 8; Woroncowa-Marcinowska 2006, Fig. 2; Stachacz et al. 2016, Fig. 3) resulted in great lateral variability. Logs presented by previous authors are difficult to correlate since different section lines were accessible over the years of study. Wider exposure shows that one horizon may end over a very short distance of a few $\mathrm{cm}$ as described above.

The interpretation of three slump horizons in the Płucki section complements similar phenomena described by 

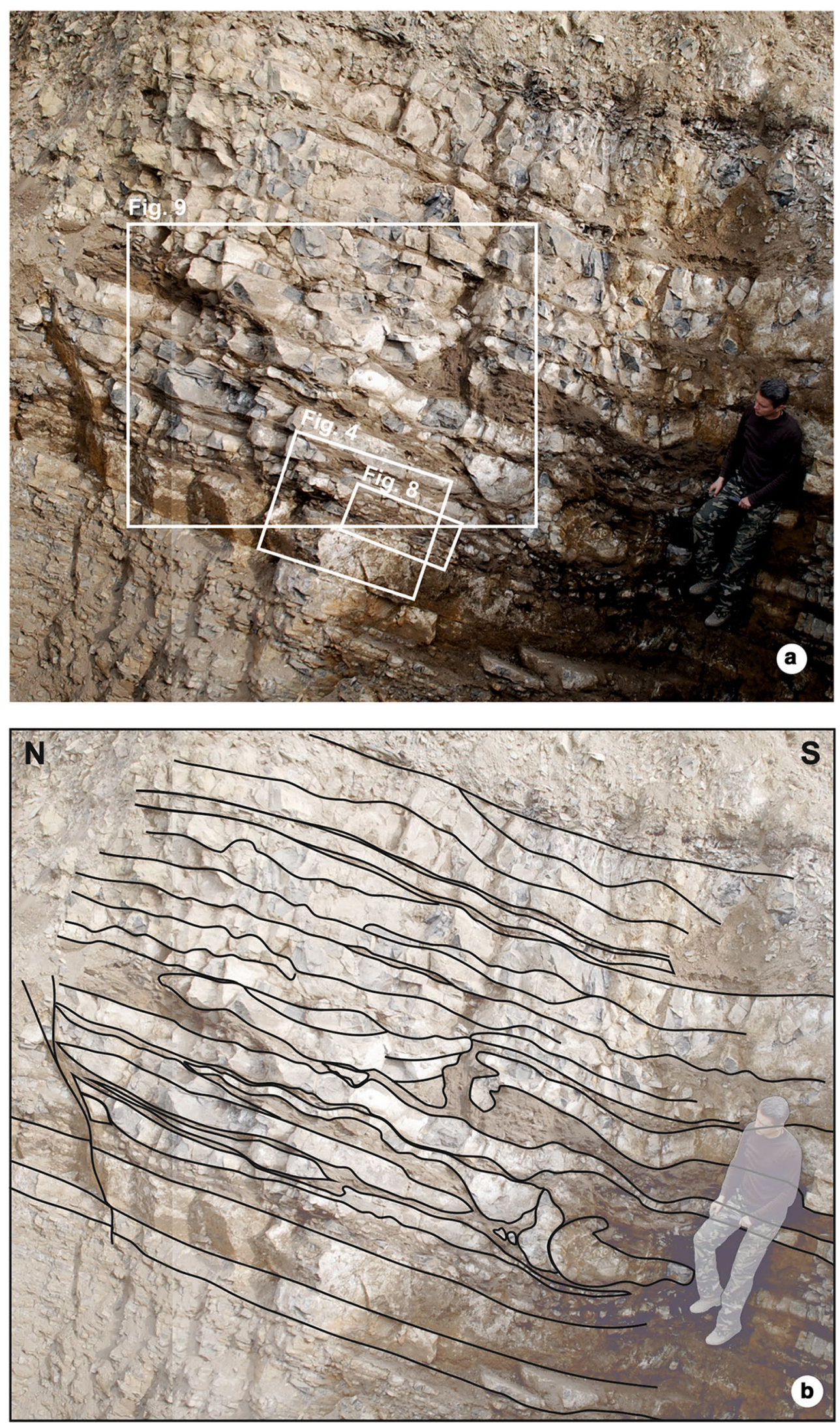

Fig. 10 a Detailed picture of the Plucki cut with a sketch showing the interpretation (b) of the structures discussed (see also Fig. 3) 
Szulczewski (1968, Figs. 3, 4) and Kazmierczak and Goldring (1978). They described large blocks of limestone and slump sheets in a Frasnian section at Kowala (about $40 \mathrm{~km}$ from Płucki), along with reef-derived clasts. The occurrence of the breccia horizon at the Frasnian-Famennian boundary in Płucki fits with other reports of a "pseudo-brecciated" lower part to the first bed of the Famennian situated at the top of the Upper Kellwasser Horizon (Szulczewski 1971; Schindler 1990, 1993; Racki et al. 2002; Gereke and Schindler 2012). The difference is that in Płucki, the "pseudobrecciation" encompasses the entire Upper Kellwasser-like horizon, including the Frasnian part.

In view of the features of the fossils, particularly the vertebrates, it is probable that their remains were transported over a geographically significant distance. The Kellwasserlike horizon is the only place in the profile where a large diversity of this fauna is identified.

The Kellwasser limestone generally consists of several dark-gray and black bioclastic wacke-/packstone beds (e.g., Buggisch 1991; Joachimski et al. 2001). The thickness of these horizons globally ranges between a few $\mathrm{cm}$ and more than $2 \mathrm{~m}$. The Lower Kellwasser Limestone occurs in the Frasnian rhenana Zone and the Upper Kellwasser Limestone at the Frasnian-Famennian boundary (linguiformis-trangularis transition). In view of this, we conclude that the horizon exposed at Płucki does not meet all the requirements and so should be named as a Upper Kellwasser-like horizon. Despite being at the same stratigraphic position, the horizon in Płucki represents a redeposited assemblage of different carbonate facies and cannot be precisely determined as Upper Kellwasser limestone (Joachimski and Buggisch 1993).

Also interesting and geologically significant is how the pinch-and-swell horizon (Unit 3) shows synsedimentary deformation which is similar to ball-and-pillow structure but differs from these by the lack of loading into the underlying bed (Knaust 2002). Deformation structures attributed to seismic activity include ball-and-pillow structures (Porter and Pettijohn 1963), pseudonodules and cycloids (Hempton and Dewey 1983), pinch-and-swell structures, and lenticular boudins, pocket-and-pillar structures (Postma 1983), flamelike structures (Visher and Cunningham 1981) and sedimentary dykes. Pinch-and-swell structures result from necking when a stiff layer and its weaker matrix are subject to layerparallel extension or layer-normal shortening (Schmalholz et al. 2008; Knaust 2002). The deformation mechanism affecting Unit 3 limestones is characterized by a lack of significant vertical loading into underlying beds and only minor horizontal disruptions of parts of the otherwise intact bed. This is atypical for the mechanism that leads to the development of ball-and-pillow structures and pseudonodules and cannot be explained by slumping on a slope. The structures at Płucki identified as pinch-and-swell structures are different from those described by Knaust (2002) from the Middle Triassic of Thuringia, Germany, mostly in their much smaller sizes when compared to the threshold of $10 \mathrm{~cm}$ of the longer axis at Płucki. Our interpretation of the origin of this horizon is that the poorly lithified limestones were disturbed by an earthquake, which initiated extension and separation of the horizon into smaller loaf-shaped fragments, which reshuffled the sedimentary strata together. In view of the well-preserved interior lamination of the nodules, which has not been rotated or erased, transportation and subsequent rotation might be excluded, such that an in situ origin of this deformation is likely for the Płucki example. Similar-sized structures have been described by Scott and Price (1988), Dugué (1995) and Calvo et al. (1998). Radwanski and Roniewicz (1962, pl. 15, Figs. 1, 2), reported similar pebblelike pseudonodules, and interpreted their origin as a result of a disruption and then a dip of the layer fragments. Such seismic structures have been described from siliciclastic successions, but deformational structures attributed to seismic liquefaction and/or fluidization have also been reported from shallow-marine carbonate successions (Cisne 1986; Pratt 1994; Pope et al. 1997; Spalluto et al. 2007; Mastrogiacomo et al. 2012).

The strongly deformed beds occurring in Unit 4 above the pinch-and-swell horizon are typical slump features with folds, rolls, multiplications (slices) and the discontinuity of beds. Imbrication of the limestone layers is common for slump deposits. Similar structures have been reported from many sites around the world in many formations including: Waterhouse and Bradley (1957, Paleogene of New Zealand), Radwanski and Roniewicz (1962, Upper Devonian of the Holy Cross Mountains, Poland), Tucker (1973, Upper Devonian of Germany), Spreng (1967, Carboniferous of Arkansas, USA), Szulczewski (1968, Upper Devonian of the Holy Cross Mountains, Poland), Gill (1979, Carboniferous of Ireland), in part, by Knaust (2002, Triassic of Germany) and by Alberti et al. (2017, Jurassic of north India).

Since the plastic deformation in Unit 4 involved the whole 4-m-thick limestone-shale package above the pinch-andswell horizon (Unit 3), we maintain that this resulted from a single slump event.

Taking into consideration all the aforementioned described geological features, a timeline for the section's deposition can be outlined as follows (Fig. 11a-e): First, the Upper Kellwasser-like horizon (Unit 2) was deposited as a series of slumps of semi-consolidated black, bituminous limestone and dolomitic limestone aggregated with dark-brown grainy limestone (Fig. 11b). The succeeding Unit 3 limestone intercalated with shale (Fig. 11c) was disturbed during an earthquake to develop pinch-and-swell-like structures (Fig. 11d). This was followed by a major slump depositing the deformed limestone shale of Unit 4 (Fig. 11e). The previously reported fragmentation of invertebrate shells 
Fig. 11 Schematic diagrams showing successive stages in the evolution of the Płucki section. a Initial stage with an undisturbed Łagów beds on a deep-marine shelf on the right and sedimentation of fossiliferous and non-fossiliferous dolomitic limestone in shallower-water area-Unit 1. b First slump event leads to the deposition of the Upper Kellwasser-like horizon-Unit 2. c Calm sedimentation above the Upper Kellwasser-like horizon. d A seismic event leads to the destabilization of the 20-cm-thick unit and to the origin of the pinch-andswell structures-Unit 3. e Second slump event leads to deposition of the deformed unit with slump rolls and sheets-Unit 4

(Rakociński et al. 2016), the occurrence of discontinuity levels (Janiszewska et al. 2007), and the above-described breccia structure of the Upper Kellwasser-like horizon with numerous abraded bones and fragments, all suggest transportation and reworking, before final deposition. The state of bone preservation differs from fragmentary fish remains affected by posthumous decomposition, which are typically disarticulated with no trace of transport. Such examples are known from contemporary deposits of the area discussed by Szrek (2004, 2007b). The abundance of fossils also supports redeposition; however, it may also have been the result of a faunal bloom. The high diversity of invertebrates (brachiopods, trilobites, bivalves, gastropods, tentaculites, cephalopods), conodonts and vertebrates represented by placoderms, chondrichthyans and actinopterygians (see, Szrek and Ginter 2008: Table 1) suggests a range of environments where these animals lived and from where their remains came.

While the ultimate causes of the occurrences of the numerous submarine slumps within the Upper Devonian of the Holy Cross Mountains (Radwański and Roniewicz 1962; Szulczewski 1968, 1971) have not been finally determined, Szulczewski (1971, 1989), Kaźmierczak and Goldring (1978), Szulczewski et al. (1996) and Skompski and Szulczewski (2000) attributed these features to tectonic activity and associated earthquakes. Near the end of the Frasnian, the carbonate complex disintegrated, with local, uplifted and eroded blocks. Since the cause of triggering mechanisms is not preserved in the sedimentary record (Shanmugam 2016), the arguments for a tectonic cause come from an analysis of the regional development of the Frasnian strata in the southern part of the Holy Cross Mountains. However, this concerns exclusively the pinch-and-swell horizon which especially shows characters indicating an origin directly related to earthquake activity. The Kellwasser horizon and the slump-and-rolls part of the section do not present any feature that could exclude storms or more generally stronger wave activity, as the triggering mechanism which led to the initiation of the slump.

The stratigraphic position of tectonic events at the Płucki section documented by slumps correlates with evidence from radiometric dating of tectonically deformed strata from other sites world-wide (e.g., Averbuch et al. 2005; McGhee 2013), demonstrating that the Late Devonian was

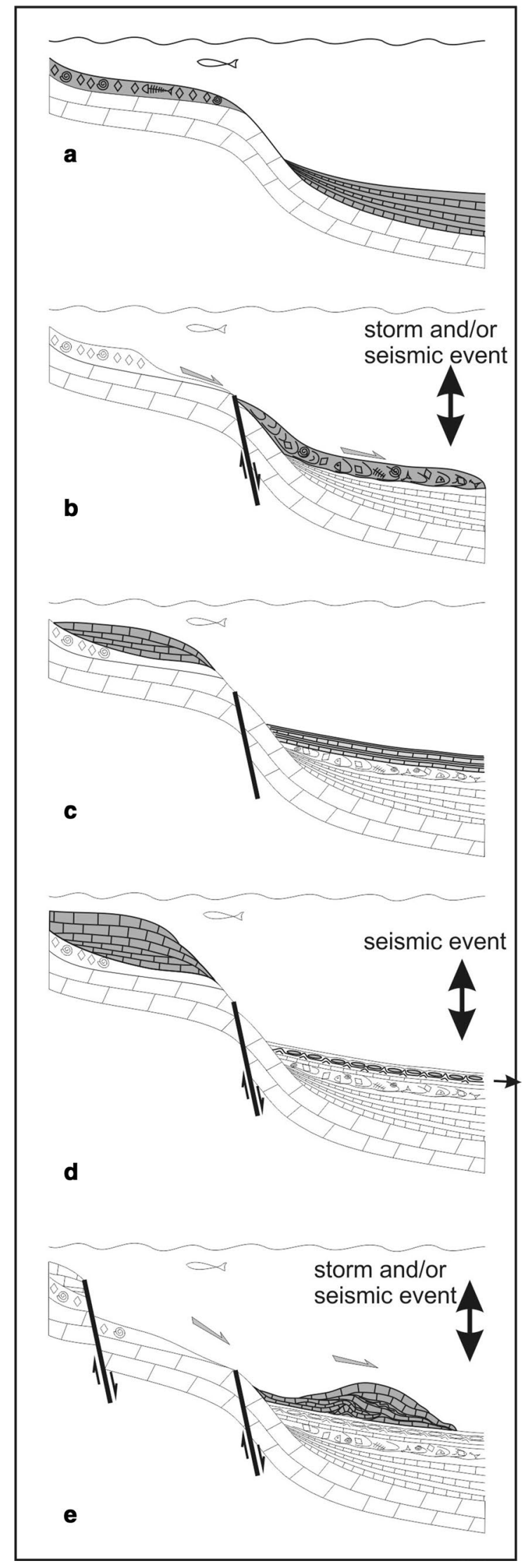


a period of intense tectonic activity (Racki 1998; McGhee 2013). This resulted from the collision of major continental crustal blocks: Laurussia, Gondwana, Kazakhstan and Siberia during the so-called Acadian-EoVariscan mountain building event (Averbuch et al. 2005; Racki et al. 2018) over the course of about 50 million years. In the Holy Cross Mountains, this tectonic activity resulted in the fragmentation of an extensive carbonate platform into blocks, as documented by three generations of neptunian dykes and deeper hydrothermal mineralization (Szulczewski 1973; Szulczewski et al. 1996), and most demonstrably as facies differentiation (Sobolev 1912; Szulczewski 1971, 1989). This tectonic activation is also linked with intraformational erosional pulses, manifested by coarse breccias and conglomerates (Radwański and Roniewicz 1962; Szulczewski 1968, 1971; Racki 1993a, b, 1999). Extensional block-tilting led to rapidly uplifted areas (reefs, shelf carbonates) on one side, and steepened slopes and deepening basins on the other. As uplifted areas were eroded, associated earthquakes in combination with steep slopes provided the seismic and gravitational energy for rapid, chaotic transport and redeposition. Intensive erosion and redeposition of breccia layers in the lowermost Famennian has also been described from Moravia (Czech Republic; Hladil and Kalvoda 1993) and attributed to a tsunami. The influence of storms on the origin of such deposits has been discussed mainly by Kaźmierczak and Goldring (1978), Racki (1993a), Racki and Narkiewicz (2000) and Vierek (2007, 2013). The Late Devonian of the Holy Cross Mountains was characterized by a tropical climate (Matyja 1993; Vierek 2013). The palaeoclimatic conditions with tropical temperatures, together with the palaeogeographical position of the Holy Cross Mountains, would have favored the influence of tropical high-energy events (hurricanes, storms) on the fossil record.

The influence of the slump within the Upper Kellwasserlike horizon on fossil preservation has resulted in positive conditions for study despite their fragmentation (for details see Szrek in press). The transport of the sediment, which contained fossils from shallower and well-oxidized parts of the basin, to deeper, anoxic conditions, probably allowed the preservation of most of the minuscule remaining fragments.

\section{Conclusions}

Recent observations suggest that the assumed continuity of strata of the Płucki section must be reconsidered and, moreover, previous conclusions based on this locality need to be revisited as the diverse nature of these sections has never been adequately explained. The new data from the debris flow and slump structures described from Plucki provide the first evidence for synsedimentary disturbances within the profile and demonstrate episodic re-sedimentation.
Numerous imbrications of beds as the result of a major slump and changes in thickness may have had an influence on results of previous studies dealing with detailed stratigraphic, geochemical and geophysical investigations. Sampling within the slumped unit in different locations may have led to spurious and confusing results depending on the sample site (Fig. 1).

The overall stratigraphic framework for the Płucki section reveals a generally continuity of beds. The age of sediments involved in slump events is confined to within one conodont Zone, including resedimentation over a relatively short period of time. The mixed character of the Kellwasser horizon and the section generally prohibits the use of the term "Upper Kellwasser Limestone" (sensu e.g., Klapper et al. 1993). This horizon at Płucki can be regarded, at least, as a "Time-Specific Facies" (Gereke and Schindler 2012).

Thus, the Upper Kellwasser-like horizon from Płucki cannot be considered suitable for studying the causes of the supposed anoxia in the context of the mass extinction that occurred at the Frasnian-Famennian boundary.

In the light of the available data, it is difficult to decide explicitly whether seismic or storm/tsunami wave activity was the triggering mechanism of the slumps and resedimentation.

Acknowledgments Grzegorz Racki is especially appreciated for many precious remarks and kind revision of the early version of the manuscript as well as Maurice Tucker and two anonymous reviewers who provided constructive reviews. We are grateful to Krystian Wójcik for help during field work and drawing a profile (Fig. 1). We thank to Marta Hodbod, Tatiana Woroncowa-Marcinowska, Marek Dec, Łukasz Gagała, Agnieszka Jaszczuk and Patrycja Dworczak for assistance during field work and to Grzegorz Wereszczyński for his help in providing the specimen presented on Fig. 7a. P.S. and S.S. were financed by the Polish Geological Institute-National Research Institute (Grant no. 61.2401.1801.00.0). P.S. is currently funded by the Polish National Science Center (Grant awarded to M. Ginter no. 2016/23/B/ST10/03262).

Open Access This article is licensed under a Creative Commons Attribution 4.0 International License, which permits use, sharing, adaptation, distribution and reproduction in any medium or format, as long as you give appropriate credit to the original author(s) and the source, provide a link to the Creative Commons licence, and indicate if changes were made. The images or other third party material in this article are included in the article's Creative Commons licence, unless indicated otherwise in a credit line to the material. If material is not included in the article's Creative Commons licence and your intended use is not permitted by statutory regulation or exceeds the permitted use, you will need to obtain permission directly from the copyright holder. To view a copy of this licence, visit http://creativecommons.org/licenses/by/4.0/.

\section{References}

Alberti M, Pandey DK, Sharma JK, Swami NK, Uchman A (2017) Slumping in the Upper Jurassic Baisakhi Formation of the 
Jaisalmer Basin, western India: sign of synsedimentary tectonics? J Palaeogeogr 6:321-332. https://doi.org/10.1016/j. jop.2017.08.001

Averbuch O, Tribovillard N, Devleeschouwer X, Riquier L, Mistiaen B, Van Vliet-Lanoe B (2005) Mountain building-enhanced continental weathering and organic carbon burial as major causes for climatic cooling at the Frasnian-Famennian boundary (c. $376 \mathrm{Ma}$ )? Terra Nova 17:25-34. https://doi.org/10.111 1/j.1365-3121.2004.00580.x

Bond D, Wignall PB, Racki G (2004) Extent and duration of marine anoxia during the Frasnian-Famennian (Late Devonian) mass extinction in Poland, Germany, Austria and France. Geol Mag 141:173-193. https://doi.org/10.1017/S0016756804008866

Bratton JF, Berry WBN, Morrow JR (1999) Anoxia predates FrasnianFamennian boundary mass extinction horizon in the Great Basin, USA. Palaeogeogr Palaeoclimatol Palaeoecol 154:275-292

Buggisch W (1991) The global Frasnian-Famennian Kellwasser event. Geol Runschau 80:49-72

Calvo JP, Rodriguez-Pascua M, Martin-Velazquez S, Jimenez S, de Vicente G (1998) Microdeformation of lacustrine laminate sequences from Late Miocene formations of SE Spain: an interpretation of loop bedding. Sedimentology 45:279-292

Cisne JL (1986) Earthquake recorded stratigraphically on carbonate platform. Nature 323:320-322

Copper P (1994) Ancient reef ecosystems expansion and collapse. Coral Reefs 13:3-11

Czarnocki J (1950) Geology of the Łysa Góra Region (Święty Krzyż Mountains) in connection with the problem of iron ores at Rudki. In: Travaux du Service Géologique de Pologne, pp 404. Warszawa (in Polish with English summary)

Czarnocki J (1989) Klimenie Gór Świętokrzyskich. Prace Instytutu Geologicznego 127:1-92 (in Polish with English summary)

Dugué O (1995) Séismites dans le Jurassique supérieur du Bassin anglo-parisien (Normandie, Oxfordien supérieur, Calcaire gréseux Hennequeville). Sed Geol 99:73-93

Dworczak P, Szrek P (2016) The Late Devonian placoderm Aspidichthys Newberry, 1873 from the Holy Cross Mountains, Poland. Fossil Record 20:9-19. https://doi.org/10.5194/fr-20-9-2016

Dzik J (1985) Phylogeny of the Nautiloidea. Palaeontologia Polonica 45:1-219

Dzik J (2002) Emergence and collapse of the Frasnian conodont and ammonoid communities in the Holy Cross Mountains, Poland. Acta Palaeontol Polonica 47:565-650. http://www.app.pan.pl/ article/item/app47-565.html

Dzik J (2006) The Famennian "Golden Age" of conodonts and ammonoids in the Polish part of the Variscan sea. Palaeontol Polonica 63:1-359

Filipiak P (2002) Palynofacies around the Frasnian/Famennian boundary in the Holy Cross Mountains, southern Poland. Palaeogeogr Palaeoclimatol Palaeoecol 181:313-324

Gereke M, Schindler E (2012) "Time-Specific Facies” and biological crises-The Kellwasser event interval near the Frasnian/ Famennian boundary (Late Devonian). Palaeogeogr Palaeoclimatol Palaeoecol 367-368:19-29. https://doi.org/10.1016/j.palae o.2011.11.024

Gill WD (1979) Syndepositional sliding and slumping in the West Clare Namurian Basin, Ireland. Geol Surv Ireland Spec Pap $4: 1-31$

Ginter M (1995) Ichthyoliths and Late Devonian events in Poland and Germany. Ichthyolith Issues 1:23-30 (Special Publication)

Ginter M (2002) Chondrichthyan fauna of the Frasnian-Famennian boundary beds in Poland. Acta Palaeontol Pol 47:329-338

Hempton MR, Dewey JE (1983) Earthquake-induced deformational structures in young lacustrine sediments, East Anatolian Fault, southeast Turkey. Tectonophysics 98:17-114
Hladil J, Kalvoda J (1993) Devonian boundary intervals of Bohemia and Moravia. Global boundary events, an interdisciplinary conference-excursion guidebook. Kielce 1993:29-50

House MR (2002) Strength, timing, setting and cause of mid-Palaeozoic extinctions. Palaeogeogr Palaeoclimatol Palaeoecol 181:5-25

Ivanov A, Ginter M (1997) Comments on the Late Devonian placoderms from the Holy Cross Mountains (Poland). Acta Palaeontol Pol 42:413-426

Janiszewska K, Szrek P, Woroncowa-Marcinowska T (2007) Zapis zdarzeń biotycznych na pograniczu frańsko-fameńskim w Płuckach koło Łagowa. In: Żylińska A (ed) Granice Paleontologii, XX Konferencja Paleobiologów i Biostratygrafów PTG, Św. Katarzyna pod Łysicą, 10-13 września 2007, Wydział Geologii Uniwersytetu Warszawskiego, pp. 63-66. (in Polish)

Joachimski M, Buggisch W (1993) Anoxic events in the late Frasnian causes of the Frasnian-Famennian faunal crisis? Geol 21:675-678

Joachimski MM, Ostertag-Henning C, Pancost RD, Strauss H, Freeman KH, Littke R, Sinninghe Damste JS, Racki G (2001) Water column anoxia, enhanced productivity and concomitant changes in $\delta 13 \mathrm{C}$ and $834 \mathrm{~S}$ across the Frasnian-Famennian boundary (Kowala-Holy Cross Mountains/Poland). Chem Geol 175:109-131

Kaźmierczak J, Goldring R (1978) Subtidal flat-pebble conglomerate from the Upper Devonian of Poland: a multiprovenant high-energy product. Geol Mag 115:359-366

Klapper G, Feist R, Becker RT, House MR (1993) Definition of the Frasnian/Famennian stage boundary. Episodes 16:433-441

Knaust D (2002) Pinch-and-swell structures at the Middle/Upper Muschelkalk boundary (Triassic): evidence of earthquake effects (seismites) in the Germanic Basin. Int J Earth Sci (Geol. Rundschau) 91:291-303

Kowalczewski Z (1971) Main geological problems of the Lower Devonian in the Świętokrzyskie Mts. Geol Q 15:263-283 (in Polish with English summary)

Ma X, Gong Y, Chen D, Racki G, Chen X, Liao W (2016) The Late Devonian Frasnian-Famennian Event in South China-patterns and causes of extinctions, sea level changes, and isotope variations. Palaeogeogr Palaeoclimatol Palaeoecol 448:224-244. https ://doi.org/10.1016/j.palaeo.2015.10.047

Makowski H (1963) Problem of sexual dimorphism in ammonites. Palaeontologia Polonica 12:1-92

Makowski H (1971) A contribution to the knowledge of Upper Devonian ammonoids from the Holy Cross Mts. Acta Geol Pol 21:131-136

Mastrogiacomo G, Moretti M, Owen G, Spalluto L (2012) Tectonic triggering of slump sheets in the Upper Cretaceous carbonate succession of the Porto Selvaggio area (Salento peninsula, southern Italy): synsedimentary tectonics in the Apulian Carbonate Platform. Sed Geol 269(270):15-27. https://doi.org/10.1016/j.sedge o.2012.05.001

Matyja H (1993) Upper devonian of western Pomerania. Acta Geol Pol 43:27-94

Matyja H, Narkiewicz M (1992) Conodont biofacies succession near the Frasnian/Famennian boundary. Some Polish examples. Courier Forschung-Inst Senckenberg 154:125-147

Matyja H, Narkiewicz M (1995) Conodont stratigraphy of the Upper Devonian in the Janczyce I borehole section, eastern Holy Cross Mts. Geol Q 39:177-206

McGhee GR Jr (2013) When the Invasion of land failed. The legacy of the Devonian Extinctions. Columbia University Press, New York, p 317

Pope MC, Read JF, Bambach R, Hofmann HJ (1997) Late Middle to Late Ordovician seismites of Kentucky, southwest Ohio and Virginia: sedimentary recorders of earthquakes in the Appalachian basin. Geol Soc Am Bull 109:489-503 
Porter PE, Pettijohn FJ (1963) Palaeocurrents and basin analysis. Springer, Berlin, p 296

Postma G (1983) Water escape structures in the context of a depositional model of a mass flow dominated conglomeratic fan delta. Sedimentology 30:91-103

Pratt BR (1994) Seismites in the Mesoproterozoic Altyn Formation (Belt Supergroup), Montana: a test for tectonic control of peritidal carbonate cyclicity. Geology 22:1091-1094

Racki G (1993a) Evolution of the bank to reef complex in the Devonian of the Holy Cross Mountains. Acta Palaeontol Pol 37:87-182

Racki G (1993b) Kellwasser events in the Łagów basin area, eastern Holy Cross Mountains. Global Boundary Events, Abstracts, 44. Warszawa

Racki G (1998) Frasnian-Famennian biotic crisis: undervalued tectonic control? Palaeogeogr Palaeoclimatol Palaeoecol 141:177-198

Racki G (1999) Silica-secreting biota and mass extinctions: survival patterns and processes. Palaeogeogr Palaeoclimatol Palaeoecol 154:107-132

Racki G (2005) Toward understanding Late Devonian global events: few answers, many questions. In: Over DJ, Morrow JR, Wingall PB (eds) Understanding late Devonian and Permian-Triassic Biotic and climatic events: Towards and Integrated Approach, pp. 5-36

Racki G, Baliński A (1998) Late Frasnian Atrypida (Brachiopoda) from Poland and the Frasnian-Famennian biotic crisis. Acta Palaeontol Pol 43:273-304

Racki G, Narkiewicz M (2000) Tektoniczne a eustatyczne uwarunkowania rozwoju sedymentacji dewonu Świętokrzyskiego. Przegląd Geologiczny 48:65-76

Racki G, Racka M, Matyja H, Devleeschouwer X (2002) The Frasnian/ Famennian boundary interval in the South Polish-Moravian shelf basins: integrated event-stratigraphical approach. Palaeogeogr Palaeoclimatol Palaeoecol 181:251-297

Racki G, Marynowski L, Rakociński M (2018) Anomalous Upper Devonian mercury enrichments: comparison of Inductively Coupled Plasma - Mass Spectrometry (ICP-MS) and AAS analytical data. Geological Quarterly 62:487-495. https://doi.org/10.7306/ gq.1419

Radwański A, Roniewicz P (1962) Submarine slumping in the Famennian of the Holy Cross Mountains (central Poland). Acta Geol Pol 12:295-304

Rakociński M, Pisarzowska A, Janiszewska K, Szrek P (2016) Depositional conditions during the Lower Kellwasser Event (Late Frasnian) in the deep-shelf Łysogóry basin of the Holy Cross Mountains (Poland). Lethaia 49:571-590. https://doi.org/10.1111/ let. 12167

Schindler E (1990) The late Frasnian (Upper Devonian) Kellwasser Crisis. Lect Notes Earth Sci 30:151-159

Schindler E (1993) Event-stratigraphic markers within the Kellwasser Crisis near the Frasnian/Famennian boundary (Upper Devonian) in Germany. Palaeogeogr Palaeoclimatol Palaeoecol 104:115-125

Schmalholz SM, Schmid DW, Fletcher RC (2008) Evolution of pinchand-swell structures in a power-law layer. J Struct Geol 30:649663. https://doi.org/10.1016/j.jsg.2008.01.002

Scott B, Price S (1988) Earthquake-induced structures in young sediments. Tectonophysics 147:165-170

Shanmugam G (2016) The seismite problem. J Palaeogeogr 5:318-362

Skompski S, Szulczewski M (2000) Lofer-type cyclothems in the Upper Devonian of the Holy Cross Mts. (central Poland). Acta Geol Pol 50:393-406

Sobolev D (1912) O verkhnem neodevone Łagowa [On the Upper Devonian of Łagów]. Izvestiya Varshavskogo Politekhnicheskogo Instituta 3:1-32 (in Russian)

Spalluto L, Moretti M, Festa V, Tropeano M (2007) Seismicallyinduced slumps in Lower Maastrichtian peritidal carbonates of the Apulian Platform (southern Italy). Sed Geol 196:81-98. https ://doi.org/10.1016/j.sedgeo.2006.06.000

Spreng AC (1967) Slump features, Fayetteville Formation, northwestern Arkansas. J Sediment Petrol 37:804-817

Stachacz M, Uchman A, Rodriguez-Tovar FJ (2016) Ichnological record of the Frasnian-Famennian boundary interval: two examples from the Holy Cross Mts (Central Poland). Int J Earth Sci 106:14. https://doi.org/10.1007/s00531-016-1308-1

Szrek P (2004) The first articulated antiarch (Vertebrata, Placodermi) from the Upper Devonian of the Holy Cross Mountains (central Poland). Acta Geol Pol 54:401-406

Szrek P (2007a) Ryby pancerne a zapis górnego zdarzenia Kellwasser w Płuckach koło Łagowa. In: Żylińska A (ed), Granice Paleontologii, XX Konferencja Paleobiologów i Biostratygrafów PTG, Sw. Katarzyna pod Łysica, 10-13 września 2007, Wydział Geologii Uniwersytetu Warszawskiego, pp 133-134 (in Polish)

Szrek P (2007b) Coelacanths (Actinistia, Sarcopterygii) from the Famennian (Upper Devonian) of Kadzielnia Chain, Holy Cross Mountains, Poland. Acta Geol Pol 57:403-413

Szrek P (2008) Vertebrates from the upper Kellwasser limestone, Frasnian-Famennian boundary beds (Upper Devonian) of the Holy Cross Mountains (Poland). In: 68th Annual Meeting Society of Vertebrate Paleontology Cleveland, Ohio USA October 15-18, 2008, J Vertebr Paleontol 28:150

Szrek P (2011) Płucki-taphonomic window overlooking the ,great Late Devonian extinction". In: Ludwikowska-Kędzia M, Wiatrak (ed), Geology and Geomorphology of the Holy Cross Mountains, Institute of Geography, Jan Kochanowski University, pp 43-52 (in Polish with English summary)

Szrek P (in press) Comments on distribution and taphonomy of Devonian placoderms in the Holy Cross Mountains, Poland. Bull Geosci $95(1)$

Szrek P, Ginter M (2007) Poziomy wapieni typu Kellwasserkalk w Płuckach koło Łagowa. In: Żylińska A (ed), Granice Paleontologii, XX Konferencja Paleobiologów i Biostratygrafów PTG, Św. Katarzyna pod Łysicą, 10-13 września 2007, Wydział Geologii Uniwersytetu Warszawskiego, pp 157-161 (in Polish with English summary)

Szrek P, Ginter M (2008) Kellwasserkalk layers at Płucki near Łagów. Ichthyolith Issues 11:46-50

Szrek P, Wilk O (2018) A large Late Devonian arthrodire (Vertebrata, Placodermi) from Poland. Estonian J Earth Sci 67:33-42. https:// doi.org/10.3176/earth.2018.02

Szulczewski M (1968) Slump structures and turbidites in Upper Devonian limestones of the Holy Cross Mountains. Acta Geol Pol 17:303-324

Szulczewski M (1971) Upper Devonian conodonts, stratigraphy and facial development in the Holy Cross Mts. Acta Geol Pol 21:1-129

Szulczewski M (1973) Famennian-Tournaisian neptunian dykes and their conodont fauna from Dalnia in the Holy Cross Mountains. Acta Geol Pol 23:15-59

Szulczewski M (1989) Światowe i regionalne zdarzenia w zapisie stratygraficznym pogranicza franu z famenem. Przegląd Geologiczny 37:551-557 (in Polish with English summary)

Szulczewski M (1995) Depositional evolution of the Holy Cross Mts. (Poland) in the Devonian and Carboniferous-a review. Geol Q 39:471-488

Szulczewski M, Belka Z, Skompski S (1996) The drowning of a carbonate platform: an example from the Devonian-Carboniferous of the Holy Cross Mountains, Poland. Sed Geol 106:21-49

Tucker ME (1973) Sedimentology and diagenesis of Devonian pelagic limestones (Cephalopodenkalk) and associated sediments of the Rhenohercynian Geosyncline, West Germany. Neues Jb Geol Paläontol Abh 142:320-350 
Vierek A (2007) Transitional reef-to-basin facies of Lower Frasnian limestones determined by microfacies analysis (Wietrznia, Holy Cross Mts, Poland). Facies 53:141-155

Vierek A (2013) The palaeogeographical background of Late Devonian storm events in the western part of the Holy Cross Mountains (Poland). Geologos 19:257-272

Visher GS, Cunningham RD (1981) Convolute laminations - a theoretical analysis: example of Pennsylvanian sandstone. Sed Geol 28:175-189

Waterhouse JB, Bradley J (1957) Redeposition and slumping in the Cretaceous-Tertiary strata of southeastern Wellington. R Soc Trans 84:519-548
Wolska W (1967) Górnodewońskie konodonty z południowozachodniego region Gór Świętokrzyskich. Acta Palaeontol Pol 12:363-455 (in Polish with English summary)

Woroncowa-Marcinowska T (2006) Upper Devonian goniatites and co-occurring conodonts from the Holy Cross Mountains: studies of the Polish Geological Institute collections. Ann Soc Geol Pol $76: 113-160$ 